\title{
Comparison of Superficial Surgical Site Infection between Delayed Primary versus Primary Wound Closure in Complicated Appendicitis
}

\author{
ALAA A.S. MOSTAFA, M.D.; MOHAMED I.H. BORAI, M.D. and MOSTAFA K. HUSSEIN GHANEMA, M.Sc.
}

The Department of General Surgery, Faculty of Medicine, Ain Shams University

\begin{abstract}
Background: Acute appendicitis is the most common cause of acute abdomen in adults. Open appendicectomy is the treatment of choice for complicated appendicitis. Perforated appendicitis has an infection rate $15-20 \%$ post-operative surgical site infection can increase morbidity. Thus it can lead to increase in post-operative pain, hospital stay, sepsis and patient dissatisfaction, Surgical Site Infection (SSI) and its associated complications like wound dehiscence, stitch sinuses, incisional hernias, hypertrophic scar and keloid formation are not only a source of discomfort for the patients but also discouraging for the surgeons. These complications prolong the post-operative stay of patient and increase the cost of treatment.
\end{abstract}

Aim of Study: To compare the efficacy of primary wound closure with delayed primary wound closure in terms of wound infection after surgery for perforated appendix and get local evidence of the effectiveness of either procedure.

Patients and Methods: This study was done between May 2018 and December 2018 in the General Surgery Department in Ain Shams University Hospital and Damietta General Hospital. The study included 50 patients presented with complicated appendicitis. The patients were divided into 2 groups A and B using lottery method. Patient in group-A underwent primary closure of the skin immediately after surgery while patients in group-B were subjected to delayed primary closure of the skin for perforated appendix.

Results: In our study, in delayed primary closure there was 2 patients with positive signs of superficial surgical wound infection but in primary closure there was 11 patients. The total post-operative hospital stay in delayed primary closure ranges from 4 to 9 days and in primary closure ranges from 3 to 9 days with no significant difference between the two groups.

Conclusion: Our study suggested that patients undergoing open appendectomy for complicated appendicitis, DPC was the preferable method for wound management than primary closure because of a lower incidence of wound infection DPC could be considered for wound management in patients with perforated appendicitis.

Correspondence to: Dr. Mostafa K. Hussein Ghanema, E-Mail: $m$ ghanema2014@yahoo.com
Key Words: Surgical site infection - Coagulase negative staphylococci - Delayed primary skin closure.

\section{Introduction}

THE most common cause of acute abdomen in young adults is acute appendicitis. It is rare in infants and elderly but common in early adult life. Before puberty the male to female ratio is equal which increases to $3: 2$ at the age of 25 [1]

Open appendicectomy was performed through right lower quadrant transverse muscle-splitting incision. The thread ties were placed on the base of the appendix. The tied-off appendiceal stump was dunk in again with purse-string suture [2]

Appendicectomy is the treatment of choice for acute appendicitis. Post-operative wound Infection can increase morbidity. Thus it can lead to increase in postoperative pain, hospital stay, sepsis and patient dissatisfaction. Non-perforated appendicitis has a reported wound infection rate of less than $10 \%$ while perforated appendicitis has an infection rate $15-20 \%$. Infection is greatest in diffuse peritonitis $(35 \%)$ [3].

In the light of CDC (The Centers for Disease Control) reports, the most widespread organism responsible for the occurrence and progress of SSI is Staphylococcus aureus, followed by Escherichia coli, Coagulase Negative Staphylococci (CNS), Pseudomonas aeruginosa, Enterococcus species, Enterobacter species, Klebsiella pneumoniae, Proteus mirabilis, Candida albicans and Streptococcus. Enlarged numbers of SSI cases have been reported with Methicillin-Resistant Staphylococcus Aureus (MRSA) species [4].

Surgical Site Infection (SSI) and its associated complications like wound dehiscence, stitch sinus- 
es, incisional hernias, hypertrophic scar and keloid formation are not only a source of discomfort for the patients but also discouraging for the surgeons. These complications prolong the post-operative stay of patient and increase the cost of treatment In order to control and reduce the rate of SSI various wound closure techniques and prophylactic measures have been tried by the surgeons but had vague results [5].

Post-operative SSI can be minimized by reducing risk factors (e.g., smoking, or glucose control), or use of established preventive procedures (e.g., prophylactic antibiotics, avoid surgical drain, and unnecessary hair removal). Closure of the wound with Delayed Primary Closure (DPC) for a contaminated wound also affected SSIs. Instead of closing a wound primarily [6]

Type of skin closure is one of the factors that can reduce the SSI thus reducing hospital stay of patients and in turn decreasing costs on health resources [7]

Delayed primary skin closure (DPC) represents a technique where no special equipment is required. It can be used when contaminated or dirty wounds are created, allowing the soft tissues to drain (and preventing accumulation of microorganisms in a confined space) before closing the skin a few days later [8].

The procedure was claimed to decrease bacterial inoculums and increase local wound resistance from increasing wound oxygenation and blood supply from developing granulation tissue. It was firstly applied to traumatic wounds and later was more widely applied to various types of operations (e.g. colonic operations, opened tibial fractures, gynecologic operations) with demonstration of good efficacy. However, these results were mainly from observational studies that may be prone to selection and confounding biases. In addition, the DPC also has its own disadvantages including pain from routine dressing, necessity for later wound suturing, and increase cost of treatments [6] .

Recent research shows that even perforated appendicitis wound can be closed primarily especially with the current antimicrobial regimes. Primary wound closure is better than delayed primary closure in terms of cosmetic outcome and patient tolerability. The most important reason for controversy between primary versus delayed primary closure after perforated appendicitis is postoperative wound infection. Studies show that infection rates in the primary closure group and delayed primary closure are (8\% 10 versus $2.7 \%$
8 respectively) and (19\% 11 versus $4.2 \% 9$ respectively [1]

Aim of the work:

The aim of this study was to compare the efficacy of primary wound closure with delayed primary wound closure in terms of wound infection after surgery for perforated appendix and get local evidence of the effectiveness of either procedure.

\section{Patients and Methods}

\section{Patients:}

This study was done between May 2018 and December 2018 in the General Surgery Department in Ain Shams University Hospital and Damietta General Hospital. The study included 50 patients presented with complicated appendicitis.

The patients were divided into 2 groups $\mathrm{A}$ and $\mathrm{B}$ using lottery method. Patient in group-A underwent primary closure of the skin immediately after surgery while patients in group-B were subjected to delayed primary closure of the skin for perforated appendix.

Inclusion criteria: Male and female patients with age (15 to 50 years). Patients presented intraoperative by complicated appendicitis.

Exclusion criteria: Pregnant women. Patients having a history of malignancy. Long term steroid use. Coagulation disorder. Severely disabled patients. Diabetic patients.

\section{Method of management:}

Pre-operative assessment:

Evaluation of patients with acute appendicitis whether it is complicated or not according to: Clinical picture:

Symptoms: The patient presented to the ER with diffuse abdominal pain which started 2 or 3 days before mostly at the right iliac fossa. Fever and vomiting in cases of perforated appendicitis which lead to generalized peritonitis.

Signs: Generalized abdominal tenderness and rebound tenderness, fever (temperature >38.5).

\section{Investigations:}

Radiological evaluation: Abdominal X-ray: For detection of perforated viscus which is presented with air under diaphragm. Pelvi-abdominal U/S: For detection of intra-peritoneal free fluid or prescence of mass. In females to exclude other gynecological problems. 
Laboratory evaluation: CBC was done for detection of elevated leukocytic count.

\section{Operative treatment:}

Timing: All cases involved in this study were informed about the surgical procedure, a written consent was obtained and all patients were operated upon within the first 6 hours after diagnosis of complicated appendicitis.

\section{Surgical technique:}

Position: All patients were operated upon while lying in a supine position.

Anesthesia: The operation was carried out under general anesthesia.

Incision: In our study we use two incisions: Grid iron incision over McBurney's point which is located one-third of the way along an imaginary line from the anterior superior iliac spine to the umbilicus. After incision of the skin and subcutaneous tissue the external oblique aponeurosis is opened, then the internal oblique muscle and The transverse abdominal muscle is divided, then the peritoneum is opened to reach the abdominal cavity.

Midline incision which is done if there is suspected huge appendicular abscess or mass or any other complication.

The incision will cut through the skin, subcutaneous tissue, and fascia, the linea alba and tranversalis fascia, and the peritoneum before reaching the abdominal cavity.

Operative steps: The appendix was identified, bluntly dividing any adhesions. The taenia coli on the caecum had been traced to locate the base of the appendix. Once mobile, the appendix and caecum had been delivered through the wound.

The tip of the appendix may be difficult to mobilize, particularly with a retrocaecal appendix, in which case a retrograde appendicectomy could be performed, tying off the base of the appendix and mesoappendix first then working distally to free the appendix. To remove the appendix a window was made in the mesoappendix adjacent to the base. Two clips were placed across the base of the mesoappendix, which was then divided and Vicryl ties were applied to ligate the vessels (contains appendicular artery).

Haemostasis was checked following removal of the clips. The base of the appendix was crushed with a heavy clip then released and placed $1 \mathrm{~cm}$ higher. The appendix was ligated at the crushed base and divided just above.
In cases of appendicular abscess, pus was evacuated with removal of the appendix. In cases of appendicular mass no dissection on the mass was done, just insertion of drain. In the presence of pus an intra-peritoneal washout with warm saline was done, then insertion of drain. Then closure of the wound in layers.

The patients were divided into 2 groups:

- Group A: Patients underwent primary closure of the skin immediately.

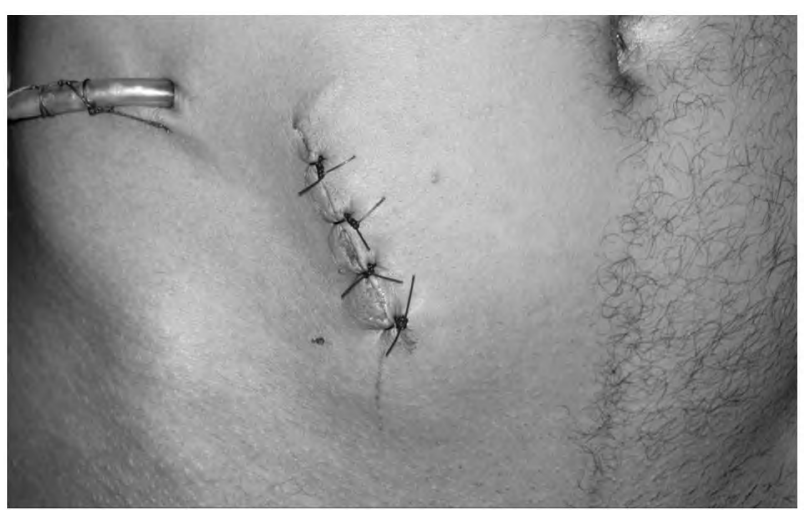

Fig. (1): Primary closure post appendectomy.

- Group B: Patients were subjected to delayed primary closure. The skin and subcutaneous tissue were left open and packed with diluted Betadine ( $0.5 \%$ povidone iodine)-soaked gauze that was changed daily to prevent excessive collection of exudate then 3 to 5 days the skin was closed under local anaesthesia.

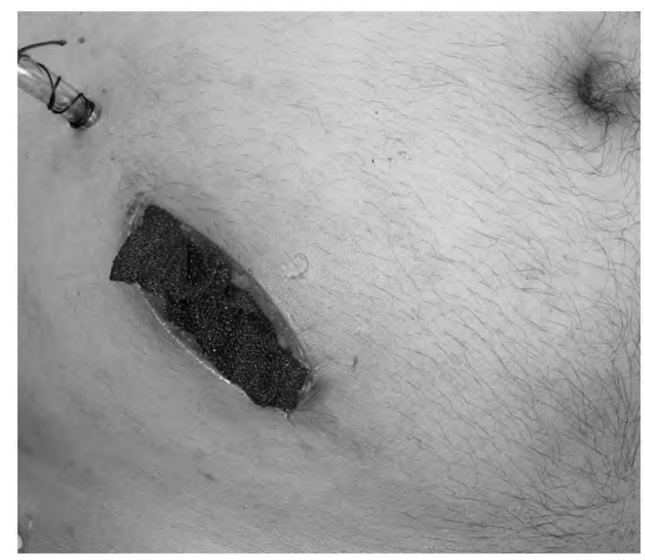

Fig. (2): Delayed primary closure post appendectomy.

Wounds were closed in either technique with prolene $2 / 0$ as suture material. The operative time was recorded for all patients.

Post-operative measures: Intravenous antibiotics (amoxicillin clavulinic acid) had been regularly prescribed in all patients for 24 to $48 \mathrm{~h}$ then switched to oral antibiotics for 7 to 10 days. Regular daily dressing of the wounds was done, with observing 
of signs of surgical site infection as localized swelling, purulent discharge, increasing erythema, induration, or warmth developed. Monitoring of the vital signs of the patient as temperature, pulse and blood pressure.

Methods of evaluation: SSI was assessed before discharging home, at 1-week and 1-month followup.

Clinical evaluation: A follow-up protocol included clinical evaluation for the pain at the surgical site, erythema, localized swelling, discharge complications were also identified and managed. This was done in the first two weeks then monthly postoperatively.

Radiological evaluation: In cases suspected with SSI superficial ultrasound was done for detection of collection.

Laboratory evaluation: In cases with wound discharge, culture and sensitivity was done for detection of the causative organism and the appropriate antibiotic.

\section{Results}

50 patients included in our study, 25 were male and 25 were females.

Table (1): Sex distribution of the study group.

\begin{tabular}{|c|c|c|c|c|c|c|c|c|}
\hline \multirow{3}{*}{ Sex } & \multicolumn{6}{|c|}{ Groups } & \multirow{2}{*}{\multicolumn{2}{|c|}{$\begin{array}{l}\text { Chi- } \\
\text { Square }\end{array}$}} \\
\hline & \multicolumn{2}{|c|}{$\begin{array}{l}\text { Delayed } \\
\text { primary } \\
\text { closure }\end{array}$} & \multicolumn{2}{|c|}{$\begin{array}{l}\text { Primary } \\
\text { closure }\end{array}$} & \multicolumn{2}{|c|}{ Total } & & \\
\hline & $\mathrm{N}$ & $\%$ & $N$ & $\%$ & $N$ & $\%$ & $x^{2}$ & $p$-value \\
\hline Male & 13 & 52.00 & 12 & 48.00 & 25 & 50.00 & 0.080 & 0.777 \\
\hline Female & 12 & 48.00 & 13 & 52.00 & 25 & 50.00 & & \\
\hline Total & 25 & 100.00 & 25 & 100.00 & 50 & 100.00 & & \\
\hline
\end{tabular}

This table shows that the mean age in cases with delayed primary closure was 24.7 and the mean age in cases with primary closure was 25.2.

Table (2): Age distribution of the study group.

\begin{tabular}{llllll}
\hline \multirow{2}{*}{ Age } & \multicolumn{2}{c}{ Groups } & & \multicolumn{2}{c}{$t$-test } \\
\cline { 2 - 3 } \cline { 5 - 6 } & \multicolumn{1}{c}{$\begin{array}{c}\text { Delayed primary } \\
\text { closure }\end{array}$} & $\begin{array}{l}\text { Primary } \\
\text { closure }\end{array}$ & & $t$ & $p$-value \\
\hline Range & $15-42$ & $16-40$ & -0.266 & 0.791 \\
Mean \pm SD & $24.720 \pm 7.840$ & $25.280 \pm 7.003$ & & \\
\hline
\end{tabular}

The duration of symptoms in cases with delayed primary closure range from 1 to 3 days, in cases with primary closure range from 2 to 4 days.
Table (3): Duration of symptoms in study group.

\begin{tabular}{|c|c|c|c|c|}
\hline \multirow{2}{*}{$\begin{array}{l}\text { Duration of } \\
\text { symptoms } \\
\text { (days) }\end{array}$} & \multicolumn{2}{|c|}{ Groups } & \multicolumn{2}{|c|}{$t$-test } \\
\hline & $\begin{array}{l}\text { Delayed primary } \\
\text { closure }\end{array}$ & $\begin{array}{c}\text { Primary } \\
\text { closure }\end{array}$ & $t$ & $p$-value \\
\hline $\begin{array}{l}\text { Range } \\
\text { Mean } \pm \text { SD }\end{array}$ & $\begin{array}{l}1-3 \\
1.880 \pm 0.781\end{array}$ & $\begin{array}{l}1-4 \\
2.360 \pm 0.860\end{array}$ & -2.066 & $0.044 *$ \\
\hline
\end{tabular}

In our study, the operative time was less than 60 minutes in 23 patients, and the operative time was more than 60 minutes in 27 patients.

Table (4): Operative time in study group.

\begin{tabular}{|c|c|c|c|c|c|c|c|c|}
\hline \multirow{3}{*}{$\begin{array}{l}\text { Operative } \\
\text { time }\end{array}$} & \multicolumn{6}{|c|}{ Groups } & \multirow{2}{*}{\multicolumn{2}{|c|}{$\begin{array}{l}\text { Chi- } \\
\text { Square }\end{array}$}} \\
\hline & \multicolumn{2}{|c|}{$\begin{array}{l}\text { Delayed } \\
\text { primary } \\
\text { closure }\end{array}$} & \multicolumn{2}{|c|}{$\begin{array}{l}\text { Primary } \\
\text { closure }\end{array}$} & \multicolumn{2}{|c|}{ Total } & & \\
\hline & $\mathrm{N}$ & $\%$ & $N$ & $\%$ & $\mathrm{~N}$ & $\%$ & $x^{2}$ & $p$-value \\
\hline$<60$ minutes & 13 & 52.00 & 10 & 40.00 & 23 & 46.00 & 0.725 & 0.395 \\
\hline$>60$ minutes & 12 & 48.00 & 15 & 60.00 & 27 & 54.00 & & \\
\hline Total & 25 & 100.00 & 25 & 100.00 & 50 & 100.00 & & \\
\hline
\end{tabular}

Post-operative pain in cases with delayed primary closure ranges from 2 to 4 and in cases with primary closure it ranges from 2 to 7 on pain scale 0 to 10

Table (5): Post-operative pain on pain scale (0-10).

\begin{tabular}{lllllll}
\hline \multirow{2}{*}{ Pain score } & \multicolumn{3}{c}{ Groups } & & \multicolumn{2}{c}{$t$-test } \\
\cline { 2 - 3 } \cline { 5 - 6 } & \multicolumn{1}{c}{$\begin{array}{c}\text { Delayed primary } \\
\text { closure }\end{array}$} & $\begin{array}{c}\text { Primary } \\
\text { closure }\end{array}$ & & $t$ & $p$-value \\
\hline Range & $2-4$ & $2-7$ & -3.383 & $0.001 *$ \\
Mean \pm SD & $2.600 \pm 0.645$ & $3.760 \pm 1.589$ & & \\
\hline
\end{tabular}

Table (6): Pain score.

\begin{tabular}{ll}
\hline 0 & - No pain. Feeling normal \\
Minor: & \\
1 very mild & Very light, barely noticeable pain \\
& - You never think about the pain
\end{tabular}


There were 9 patients with wound swelling in the study group which is distributed as follow, 1 patient with delayed primary closure and 8 patients with primary closure.

Table (7): Post-operative wound swelling in study group.

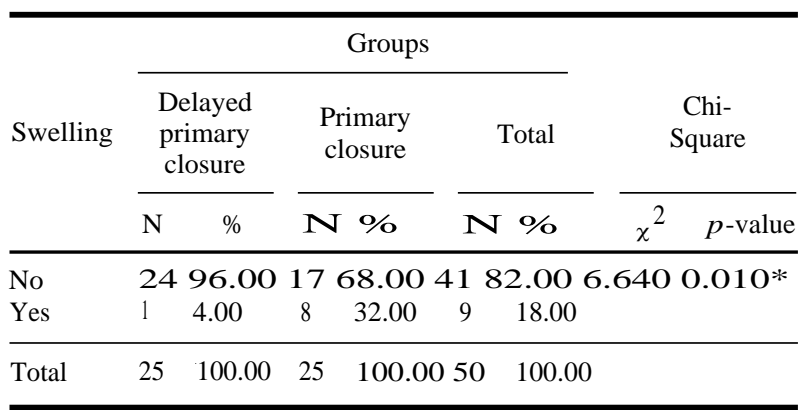

There were 7 patients with wound discharge in the study group which is distributed as follows, 1 patient in delayed primary closure and 6 patients in primary closure.

Table (8): Post-operative wound discharge in study group.

\begin{tabular}{|c|c|c|c|c|c|c|c|c|}
\hline \multirow{3}{*}{ Discharge } & \multicolumn{6}{|c|}{ Groups } & \multirow{2}{*}{\multicolumn{2}{|c|}{$\begin{array}{l}\text { Chi- } \\
\text { Square }\end{array}$}} \\
\hline & \multicolumn{2}{|c|}{$\begin{array}{l}\text { Delayed } \\
\text { primary } \\
\text { closure }\end{array}$} & \multicolumn{2}{|c|}{$\begin{array}{l}\text { Primary } \\
\text { closure }\end{array}$} & \multicolumn{2}{|c|}{ Total } & & \\
\hline & $\mathrm{N}$ & $\%$ & $N$ & $\%$ & $N$ & $\%$ & $x^{2}$ & $p$-value \\
\hline No & 24 & 96.00 & 19 & 76.00 & 43 & 86.00 & 4.153 & $0.042 *$ \\
\hline Yes & 1 & 4.00 & 6 & 24.00 & 7 & 14.00 & & \\
\hline Total & 25 & 100.00 & 25 & 100.00 & 50 & 100.00 & & \\
\hline
\end{tabular}

The total post-operative hospital stay in delayed primary closure ranges from 4 to 9 days and in primary closure ranges from 3 to 9 days with no significant difference between the two groups.

Table (9): Total post-operative hospital stay in the study group.

\begin{tabular}{llllll}
\hline \multirow{2}{*}{$\begin{array}{l}\text { Hospital } \\
\text { stay (days) }\end{array}$} & \multicolumn{2}{c}{ Groups } & & \multicolumn{2}{c}{$t$-test } \\
\cline { 2 - 3 } \cline { 5 - 6 } & $\begin{array}{c}\text { Delayed primary } \\
\text { closure }\end{array}$ & $\begin{array}{l}\text { Primary } \\
\text { closure }\end{array}$ & & $t$ & $p$-value \\
\hline Range & $4-9$ & $3-9$ & & -0.623 & 0.536 \\
Mean \pm SD & $5.000 \pm 1.155$ & $5.280 \pm 1.926$ & & \\
\hline
\end{tabular}

In our study there was 13 patients with superficial surgical wound infection. There was significant difference between the two groups of patients. In delayed primary closure there were 2 patients with positive signs of superficial surgical wound infection but in primary closure there were 11 patients.

The most common organisms cultured from the wounds were Escherichia coli (46.1\%), Bacteroides fragilis (23\%), and various Streptococci (15\%).
Table (10): The difference between the two groups of patients in superficial surgical wound infection.

\begin{tabular}{|c|c|c|c|c|c|c|c|c|}
\hline \multirow{3}{*}{$\begin{array}{l}\text { Patients } \\
\text { with } \\
\text { superficial } \\
\text { surgical } \\
\text { wound } \\
\text { infection }\end{array}$} & \multicolumn{6}{|c|}{ Groups } & \multirow{2}{*}{\multicolumn{2}{|c|}{$\begin{array}{c}\text { Chi- } \\
\text { Square }\end{array}$}} \\
\hline & \multicolumn{2}{|c|}{$\begin{array}{l}\text { Delayed } \\
\text { primary } \\
\text { closure }\end{array}$} & \multicolumn{2}{|c|}{$\begin{array}{l}\text { Primary } \\
\text { closure }\end{array}$} & \multicolumn{2}{|c|}{ Total } & & \\
\hline & $\mathrm{N}$ & $\%$ & $N$ & $\%$ & $N$ & $\%$ & $x^{2}$ & $p$-value \\
\hline Negative & 23 & 92.00 & 14 & 56.00 & 37 & 74.00 & 8.420 & $0.004^{*}$ \\
\hline Positive & 2 & 8.00 & 11 & 44.00 & 13 & 26.00 & & \\
\hline Total & 25 & 100.00 & 25 & 100.00 & 50 & 100.00 & & \\
\hline
\end{tabular}

Table (11): The result of culture from wound discharge.

\begin{tabular}{|c|c|c|c|c|c|c|c|c|}
\hline \multirow{3}{*}{$\begin{array}{l}\text { Wound pus } \\
\text { culture }\end{array}$} & \multicolumn{6}{|c|}{ Groups } & & \\
\hline & \multicolumn{2}{|c|}{$\begin{array}{c}\text { Delayed } \\
\text { primary } \\
\text { closure }\end{array}$} & \multicolumn{2}{|c|}{$\begin{array}{l}\text { Primary } \\
\text { closure }\end{array}$} & \multicolumn{2}{|c|}{ Total } & \multicolumn{2}{|c|}{$\begin{array}{l}\text { Chi- } \\
\text { Square }\end{array}$} \\
\hline & $\mathbf{N}$ & $\%$ & $N$ & $\%$ & $\mathrm{~N}$ & $\%$ & $x^{2}$ & $\begin{array}{c}p- \\
\text { value }\end{array}$ \\
\hline - No growth & 0 & 0.00 & 1 & 9.09 & 1 & 7.69 & 0.997 & 0.318 \\
\hline - Escherichia coli & 2 & 100 & 4 & 36.36 & 6 & 46.15 & 0.791 & 0.374 \\
\hline - Bacteroids fragilis & 0 & 0.00 & 3 & 27.27 & 3 & 23.08 & 0.005 & 0.944 \\
\hline $\begin{array}{l}\text { - Streptococcal } \\
\text { species }\end{array}$ & 0 & 0.00 & 2 & 18.18 & 2 & 15.38 & 0.168 & 0.682 \\
\hline $\begin{array}{l}\text { - Pseudomonas } \\
\text { aeruginosa }\end{array}$ & 0 & 0.00 & 1 & 9.09 & 1 & 7.69 & 0.997 & 0.318 \\
\hline - Clostridial species & 0 & 0.00 & 0 & 0.00 & 0 & 0.00 & - & - \\
\hline
\end{tabular}

\section{Discussion}

The aim of work of the present study was to compare the efficacy of primary wound closure with delayed primary wound closure in terms of wound infection after surgery for perforated appendix and get evidence of the effectiveness of either procedure. To achieve this aim 50 patients with acute appendicitis were included in the study.

In the present study, regarding to sex the delayed primary closure group and the primary closure group were nearly similar with $p=0.777$, which agrees with the study done by Siribumrungwong et al. [6] who found no difference with $p=0.42$.

In our study, the mean age in cases with delayed primary closure was 24.7 and the mean age in cases with primary closure was 25.2 that as nearly to the study reported by Chiang et al., [9] which found that the mean age in cases with delayed primary closure was 38.2 and the mean age in cases with primary closure was 37.5 .

Regarding to the duration of symptoms in cases with delayed primary closure, it range from 1 to 3 days but in cases with primary closure, it range from 2 to 4 days, in the study done by Meka and Anasuri [10] the mean duration of symptoms before admission was 24 hours, with a range of 1 to 4 days. 
As regard to the operative time, there was no significant difference in between the studied groups (DPC, PC) with $p=0.395$ which in agreement with the study done by Meka and Anasuri [10] who have the same results.

In the current study, there was high significant difference in between the two groups as regard to post-operative pain on pain scale with $p=0.001$ but in the study done by Siribumrungwong et al., [6] the mean post-operative pain scores were not different.

In our study, in post-operative wound discharge there was a significant difference in between the study groups with $p=0.042$, which disagrees with the study done by Siribumrungwong et al., [6] who stated that there was non-significant difference in between the study groups with $p=0.77$.

The total post-operative hospital stay in delayed primary closure ranges from 4 to 9 days and in primary closure ranges from 3 to 9 days with no significant difference between the two groups $(p=0.536)$, which agrees with the study done by Siribumrungwong et al., [6] who found no significant difference between the two groups. But that was in contrast to the previous systematic review and meta-analysis that found longer LOS in DPC than PC [6].

As regard to post-operative surgical site infection, 13 patients shows positive signs for superficial surgical site infection with overall rate about $26 \%$ where in the study done by Meka and Anasuri [10] there was 20 patients had superficial incisional SSI, overall rate of $23.2 \%$. Korol et al., [11] findings, median SSI incidence was $3.7 \%$, ranging from $0.1 \%$ to $50.4 \%$.

In the present study, in delayed primary closure there was 2 patients with positive signs of superficial surgical wound infection but in primary closure there was 11 patients. Our results are nearly similar to findings by Duttaroy et al., [12] which demonstrated much higher superficial SSI in PC than DPC (i.e, $45.2 \%$ vs. $2.7 \%$ ).

Our results were different from the previous systematic review and meta-analysis, which demonstrated similarly lower superficial SSI in PC than in DPC groups, that is, $23 \%(12 \%, 33 \%)$ versus $26 \%(10 \%, 42 \%)$, respectively [6].

These different results might be due to heterogeneous patients with different types of operation (appendicitis, other procedures), types of patients (adult, children), and incision (midline, right lower quadrant). As a result, there should be caution in applying the results of these findings to patients.

There was significant difference between the two groups of patients regarding to post-operative surgical site infection with $p=0.004$ which was different in comparative to the study done by Siribumrungwong et al., [6] where no difference between the two groups regarding to post-operative surgical site infection with $p=0.12$.

In our study, the most common organisms cultured from the wounds were Escherichia coli $(46.1 \%)$, Bacteroides fragilis (23\%), and various Streptococci $(15 \%)$ which are similar with the study done by Chiang et al., [9] who found that the most common organisms cultured from the wounds were Escherichia coli followed by Bacteroides fragilis. but in the study done by Siribumrungwong et al., [6] the most common organisms cultured from the wounds were $\mathrm{P}$ aeruginosa followed by Escherichia coli.

It is also different from the study done by Kache et al., [13] which shows that the most common organism cultured from the wounds are E. coli $13 \%$, Klebsiella $17 \%$, Pseudomonas $21 \%$, Staphylococcus aureus $9 \%$, coagulase negative staphylococci $4 \%$, enterococci $4 \%$ and sterile $36 \%$.

Bahar et al., [14] conducted an observational study which was carried out on 400 patients with gangrenous or perforated (50\%) and simple appendicitis $(50 \%)$. Both groups underwent primary wound closure. Patients were followed for wound infection for at least one month after surgery. Data including age, sex, operating time, pathologic report and wound infection were collected. A comparison between the studied groups was made using Student's $t$-test for continuous variables and 2 test for categorical variables. The median age of the patients was 23 years. There were 141 (35.2\%) females and $259(64.8 \%)$ males. The median operating time was 30 minutes. Wound infections were observed in 15 patients (3.7\%), including 6 cases of simple and 9 cases of gangrenous or perforated appendicitis which was not statistically significant.

\section{Conclusion:}

Our study suggested that patients undergoing open appendectomy for complicated appendicitis, DPC was the preferable method for wound management than primary closure because of a lower incidence of wound infection DPC could be considered for wound management in patients with perforated appendicitis. 


\section{References}

1- AHMAD M., ALI K., LATIF H., NAZ S. and SAID K. Comparison of primary wound closure with delayed primary closure in perforated appendicitis. Journal of Ayub Medical College Abbottabad, 26 (2): 153-7, 2014.

2- SUH Y.J., JEONG S.Y., PARK K.J., PARK J.G., KANG S.B., KIM D.W., OH H.K., SHIN R. and KIM J.S.: Comparison of surgical-site infection between open and laparoscopic appendectomy. Journal of the Korean Surgical Society, 82 (1): 35-9, 2012.

3- ALI K., LATIF H. and AHMAD S.: Frequency of wound infection in non-perforated appendicitis with use of single dose pre-operative antibiotics. Journal of Ayub Medical College Abbottabad, 27 (2): 378-80, 2015.

4- TARIQ A., ALI H., ZAFAR F., SIAL A.A., HAMEED K. and NAVEED S.: A systemic review on surgical site infections: Classification, risk factors, treatment complexities, economical and clinical scenarios. J. Bioequiv. Availab., 9: 336-40, 2017.

5- IMRANA A., BALOCH Q., ZAHEER F. and IQBAL M.: Delayed Primary wound closure versus primary wound closure-a dilemma in contaminated abdominal surgeries. J. Liaquat. Uni. Med. Health Sci., 14 (03): 5, 2015.

6- SIRIBUMRUNGWONG B., NOORIT P., WILASRUSMEE C. and THAKKINSTIAN A.: A systematic review and meta-analysis of randomised controlled trials of delayed primary wound closure in contaminated abdominal wounds. World Journal of Emergency Surgery, 9: (1): 49, 2014.

7- ASMA B.: A comparison of primary closure vs. delayed primary closure in contaminated abdominal surgery in terms of surgical site infection. Isra Medical Journal, 8: 150-3, 2017.
8- BHANGU A., SINGH P., LUNDY J. and BOWLEY D.M.: Systemic review and meta-analysis of randomized clinical trials comparing primary vs delayed primary skin closure in contaminated and dirty abdominal incisions. JAMA Surgery, 148 (8): 779-86, 2013.

9- CHIANG R.A., CHEN S.L. and TSAI Y.C.: Delayed primary closure versus primary closure for wound management in perforated appendicitis: A prospective randomized controlled trial. Journal of the Chinese Medical Association, 75: (4): 156-9, 2012.

10- MEKA M. and ANASURI B.: Comparison of superficial site infection between delayed primary and primary wound closures in ruptured appendicitis. International Surgery Journal, 5 (4): 1354, 2018.

11- KOROL E., JOHNSTON K., WASER N., SIFAKIS F., JAFRI H.S., LO M. and KYAW M.H.: A Systematic Review of Risk Factors Associated with Surgical Site Infections among Surgical Patients. PLoS ONE, 8: (12): e83743, 2013

12- DUTTAROY D.D., JITENDRA J., DUTTAROY B., BANSAL U., DHAMEJA P., PATEL G. and MODI N.: Management Strategy for Dirty Abdominal Incisions: Primary or Delayed Primary Closure? A Randomized Trial. Surgical Infections, 10: (2): 129-36, 2009.

13- KACHE S.A., MSHELBWALA P.M. and AMEH E.A. Outcome of primary closure of abdominal wounds following laparotomy for peritonitis in children. African journal of paediatric surgery: AJPS, 13 (4): 185-8, 2016.

14- BAHAR M.M. JANGJOO A., AMOUZESHI A. and KAVIANIFAR K.J.: Wound infection incidence in patients with simple and gangrenous or perforated appendicitis, 13: (1): 13, 2010 


\title{
دراسة مقارنة بين نسب عدوى الجرح السطحية

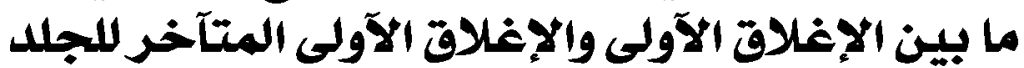

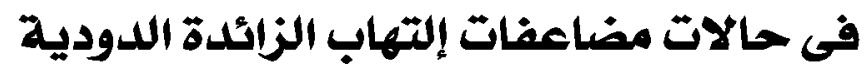

\author{
يعتبر إلتهاب الزائدة الدودية الحاد هو آحد الآسباب الآكثر شيوعاً لحالات آلام البطن فى البالغين.
}

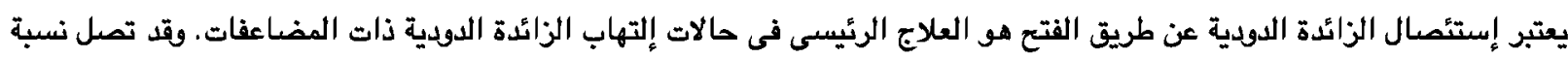

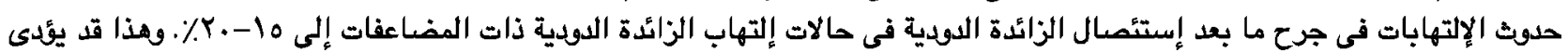

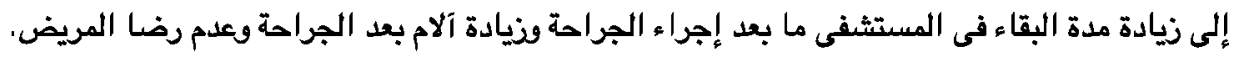

المستخلص من البحث: تهدف هذه الدراسة المقارنة بين الإغلاق الآولى الجرح، والإغلاق الآولى المتآخر في حالات إلتهاب الزائدة الدودية

ذات المضاعفات.

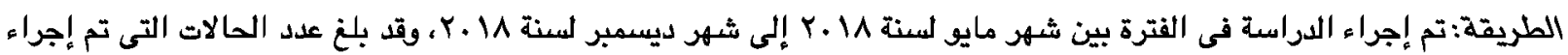

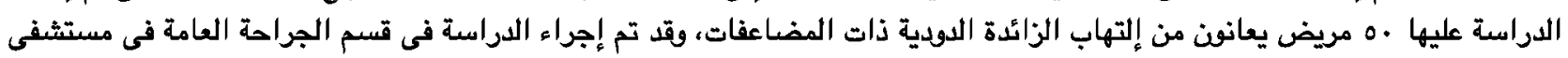

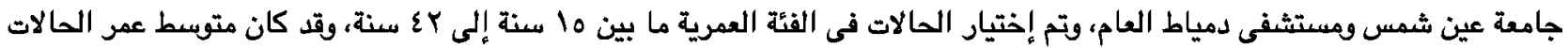

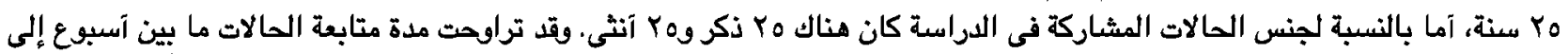

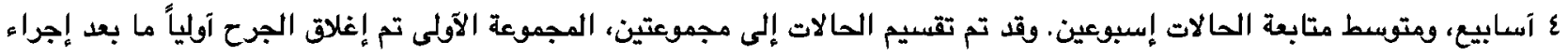

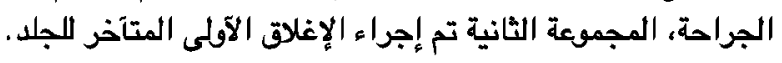

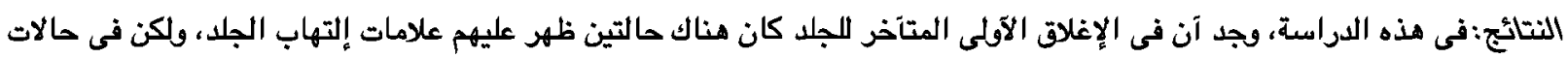

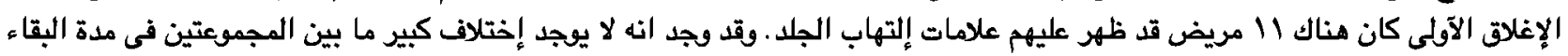
فى المستشفى ما بعد إجراء الجراحة.

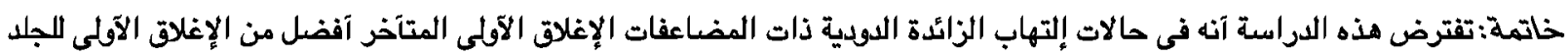

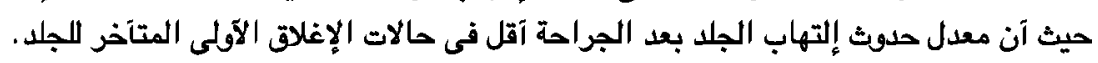

